\title{
KEEPING IN TOUCH THE NEED FOR COMMUNICATION IN PHYSIOTHERAPY
}

\author{
P. BOWERBANK M.C.S.P., BA, Dip TertEd $\dagger$ (UNISA)
}

\section{SUMMARY}

The need for communication, at all levels, in physiotherapy, is stressed. Communication is defined and characteristics of the communication model are given, viz. openness, empathy, support, positiveness, equality, content and relationships. Areas of communication such as verbal communication, listening, nonverbal communication, touch, proximity, facial expression and written communication are discussed.

The title of this paper the need for communication in physiotherapy' suggests that there is a certain lack

* Chief Physiotherapist, Groote Schuur Hospital. Paper delivered at SASP Congress held in Pretoria March 1981.

Received 29 March 1981.

\section{OPSOMMING}

Die behoefte aan kommunikasie, op alle vlakke, in fisioterapic, word beklemtoon. Kommunikasie word gedefinieer en kenmerke van die kommunikasiemodel word gegee, nl. openlikheid, empatie, ondersteuning, posiiwiteit, gelykheid, inhoud en verhoudings. Areas van kommunikasie soos mondelinge kommunikasie, luister, nie-mondelinge kommunikasie, aanraking, habyheid, ge-. sigsuitdrukking en geskrewe kommunikasie word bespreek.

of communication or that the communication process is not being effectively carried out by physiotherapists. A study of the literature suggests that this statement might possible be true. From an article by Judith Lorber (1975) I quote:

When a patient enters hospital, he or she is an outsider in the health professional's place of work. Like any other workers, doctors, nurses (physio 
COMMUNICATOR

A
MESSAGE

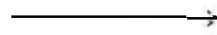

COMMUNICATOR B

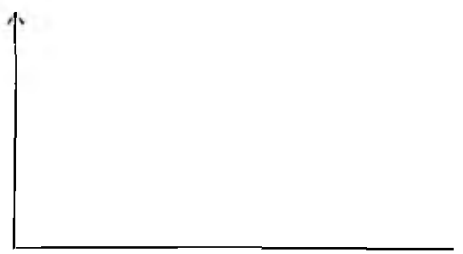

FEED BACK

THE COMMUNICATION PROCESS

Fig 1.

therapists) try to arrange for their work to be conveniently and easily performed.

The ideal situation would be to have the patient's self go home while the damaged physical container is left for repair. The medical staff certainly does have superior knowledge and expertise for the task of treatment and the patient can never be a true equal in this area. Nevertheless, it has been argued that over and above what derives from professional expertise, doctors, nurses (and physiotherapists) deliberately limit the communication of information to patients. In addition to shielding them from criticism of patients, limited communication protects the professional stance of detachment and concern. Medical care imposes on the patients a role characterised by submission to professional authority, enforced co-operation and depersonalised status. (Italics author's addition.) true.

Rather a horrifying situation but regrettably so often

I would like to suggest that physiotherapists by the nature of their profession are orientated primarily towards treatment of physical disabilities and simultaneously must be concerned with the need to establish and maintain an effective relationship with the patient. To quote Helen Hislop (1975) who paraphrased Lewis Carroll:

"The time has come, it may be said

to dream of P.T.'s role

of life and limbs and hearts and minds

of sciences and goals".

In order to know how we are to set about those lreams it is necessary to understand what the word communication means.

\section{DEFINITION}

Communication comes from the same roots as community and communion, all of which refer to a number of people holding something in common, that of sharing an experience. Communication between people forms one of man's most basic needs. Human beings are social animals. People need other people. Most of us need other people to talk to and have them talk to us; we need to show affection and have it retumed, and we like to like others and have them like us. Communication is a process, i.e. it is something that is created by man and does not have a beginning or end. All the ingredients within a process interact and all affect each other. Communication can therefore be defined as:

- A process whereby an individual shares his ideas, opinions, values and feelings with others.

- Communication is the purposeful expression and interpretation of messages.

Thus COMMUNICATION = Messages, reception and interpretation.
RECEPTION AND INTERPRETATION $=$ Listening, looking and touching.

\section{COMMUNICATION MODEL}

Looking at this in model forms (Figure 1) it is obvious that communication is:

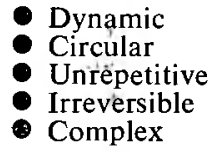

Communicator $\mathrm{A}$ is the person who intentionally starts to express herself and Communicator B would be the recipient to whom the expression is diverted. Expression is the introduction of a certain matter which is intentionally pursued by the communicator. It is the action on the part of the communicator which not only contains her purpose or aim, but also her feelings and attitudes towards something. This may often be reflected by feelings, intentions or attitudes. The message refers to that which the communicator wishes to share with the recipient. The credibility of the message is said to depend on the communicator's expertise, his intention and his trustworthiness.

It is probably true to say that many of our messages are misunderstood or only partially understood. The communicator may be at fault through poor timing, an inappropriate setting, or the way in which she delivered the message, or the difficulty may be that the message was overloaded. A high risk message would be an incomplete or very complicated one. Consider this rhyme:

The centipede was happy quite until a toad in fun said

"Pray which leg goes after which?"

that worked her mind to such a pitch

she lay distracted in a ditch considering how to run.

So many of our messages are like this: Come on granny, move your left leg right crutch right leg left crutch etc.

Interpersonal communication can vary from being extremely effective to extremely ineffective and depends on the following: (Figure 2)

\section{INTERPERSONAL COMMUNICATION}

\section{Openness}

For effective interpersonal communication to take place the communicators must:

- Be willing to open up with the person with whom they are interacting.

- Be willing to communicate honestly.

- Acknowledge that the feelings and thoughts are 
unique to each person and accept responsibility for them.

Fig. 2 .

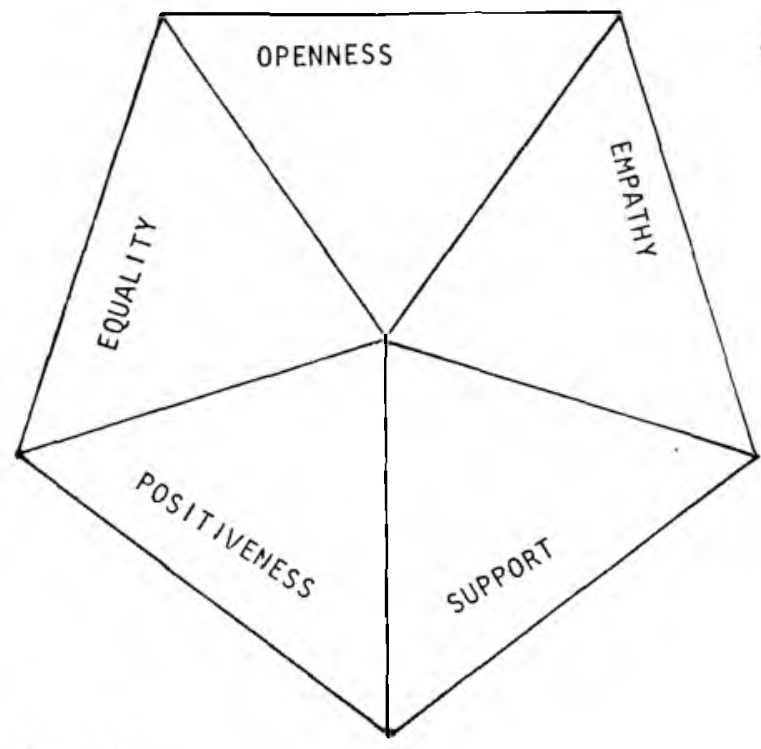

Empathy

"To feel with." This could be described as the ability of one person to know what another is experiencing at any given moment and to be able to communicate understandingly. It is not the same as sympathy. It is a trait which is often found to be deficient in health professional. Purtilo (1976) has decribed the hospital environment as stimulating fear in the patient, uprooting him from his daily pattern and placing him in a dependant state. The physiotherapist's daily contact with the patients in helping them to adjust to their new environment requires considerable empathy. It is the inner experience of sharing and comprehending the momentary psychological state of another.

\section{Support}

Some people who become ill or injured need more support than others, but almost all experience some confusion in the face of disruption and need to be reassured. Giving support also infers a certain state of dependency. This will be exhibited by the out-patient as well as the in-patient; by the patient who has a short acute illness that will lead to complete recovery as well as by the permanently disabled patient who needs

\section{Positiveness}

The communicator must show:

- Certain positive regard for self which must be conveyed to people.

- Positive feelings towards the other person regardless of colour, class or creed.

- Positive feeling for communication.

\section{Equality}

This is a peculiar characteristic. In all situations there is probably going to be some inequality of status. However in terms of speaking and listening there must be a tacit arrangement and recognition that each party's share of the communication is equally valuable.

We tend to develop a certain snobbishness about communication. We assume nothing can be gained from such interactions and that time could be better spent From such communications we realise they can in fact be enjoyable, profitable and generally rewarding.

\section{EFFECTIVENESS OF MESSAGE}

The effectiveness of the message is going to depend considerably on how the relationships develop and occur. Any message can be analysed on at least two levels:

\section{Content and Relationships}

The level of content consists of what you want to accomplish as you communicate - the work ethic. The level of relationship consists of clues in a message which relate primarily to how communicators feel about each other. Relationships depend on the degree of closeness; trust and interpersonal sharing which occurs. Car Rogers (Hooper, 1979) has called this the acessibility function of a relationship and states: "A relationship in which at least one of the parties has the intent of promoting growth development, maturity, improved functioning, improved coping with the life of others."

Surely this is much of what physiotherapy is all about. Relationships also depend on how much the communicators know about each other, this can be represented by the Johari window. (Figure 3).

The Johari window represents a total person relating to another person or persons.

The 4 window panes represent 4 kinds of information about the person.

Window 1 represents things the person knows about himself and lets others know openly.

Window 2 represents information others can see but of which the person is unaware.

Window 3 represents information about himself of which the person is aware but unwilling to disclose.

Window 4 refers to items which are totally unknown to both self and others.

The most interpersonally rewarding type of interaction is that which enlarges the open window (Figure 4). The Johari window can be used to indicate a person's general openness to others; this is collectively called selfdisclosure. Selfdisclosure can be personal and rewarding but it can at the same time be risky. This type of relationship brings in the nonjudging aspect of a person.

\section{AREAS OF COMMUNICATION}

I would now like to briefly discuss the different areas of communication which are vitally important to physiotherapists in their work with patients or students or among themselves.

These can be classified into verbal, nonverbal and written communications. One study of adults by Derito (1980) found that $70 \%$ of the day was spent in the following communication activities: listening $45 \%$; talking $32 \%$; reading $12 \%$; writing $11 \%$.

\section{Verbal Communication}

Every person in the process of living develops a style of communication used in encounters with others. When people communicate verbally much of themselves is also being communicated. Besides the words he uses the personality of the individual and his emotions are also included in verbal communication. Within the framework of verbal communication physiotherapists advise, consult, counsel and teach. 
THE JOHARI WINDOW

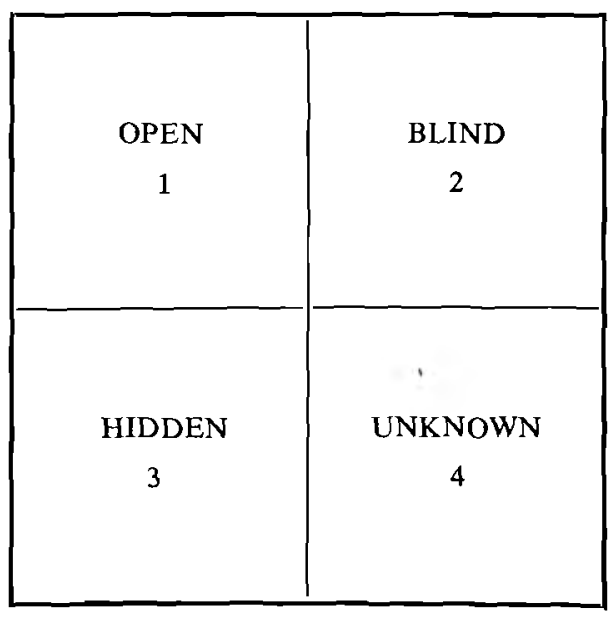

Fig. 3.

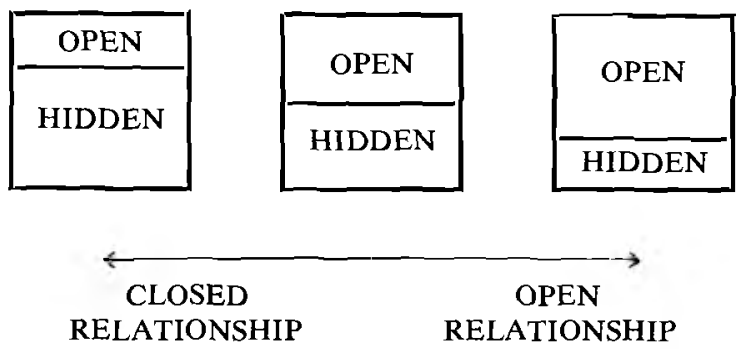

Fig. 4.
Successful verbal communication challenges a physiotherapist's energy, time, talents and individuality. We cannot be lazy or stingy in our efforts to communicate verbally.

For a physiotherapist to be able to discuss issues in depth means that she has some knowledge of the person or subject and is willing to explore the topic with another and to listen to other points of view. The focus of the conversation or interview is on sharing, exchanging and questioning. One of the things Geoff Maitland taught me, apart from mobilising techniques, was the importance of sitting down with a patient and finding out exactly what is the problem by talking and questioning.

\section{Listening}

We cannot discuss verbal communication without considering listening. We spend a great deal of time jistening, but most people are very inefficient at listenng. This includes failure to grapple with difficult pre. sentations, failure to organise the thoughts of the speaker in the listener's mind and close-minded rejection of messages before we hear them out. Listening is a skill requiring active participation in the event. Carl Rogers (Hooper, 1979) has stated: "Active listening carries a strong element of personal risk - we risk being changed - we risk coming to see the world as he sees it. It is threatening to give up, even momentarily, what we believe and start thinking in someone else terms."

Conine (1976) reports that physiotherapists spent $45 \%$ of their time in listening, with probably only a $25 \%$ efficiency. The state of fear and loneliness experienced by the patients in today's medical institution often goes by unrelieved, and the physiotherapist may be the only professional worker who can lend an ear whilst carrying out her share of the patient's fragmented care. In many instances the patient is only seeking an accepting attentive person who will give him a chance to talk about his feelings and anxieties. Listening to a patient is often all that is needed, since once relieved, the individual can usually go ahead and use his energies constructively.

\section{Nonverbal Communication}

Jan Perry (1975) states that verbal communication accounts for only $7 \%$ of communication of feelings but nonverbal communication accounts for $93 \%$. Nonverbal communication is the exchange of information through nonlinguist signs. A sign is a stimulus which for some communicator "stands for" something else whilst most of us are used to thinking of communicating in words - nonverbal communication content often cannot be translated into words e.g. a shrug of the shoulder.

Whilst reviewing literature on nonverbal communication I came across two magnificent articles on its use during physiotherapy treatments. They are by Jan Perry and Ruth Purtilo. I have based much of the next part of my paper on these articles.

\section{Touch}

Touch is perhaps the most primitive form of communication. In terms of sense development it is probably the first to be utilised. Soon after birth the child is fondled, caressed, patted and stroked by parents and friends. Touch becomes for the child a pleasant pastime and so he or she begins to touch himself, his mother and objects. Brain injured children will often cuddle a doll before performing other activities.

The very powerful role of touch as a form of communication in sexual activity is obvious. It also plays a primary role in consoling another individual - we will put our arms around to comfort, or we will hold the hands of an elderly or agitated patient.

For the physiotherapist touch offers a strong and potent form of nonverbal communication. In the physiotherapist/patient relationship touch is not only allowed, it is essential in treatment. The touch during treatment can tell the patient much of what the therapist's feelings are, whether they be encouraging, gentle, unsure, hurried or uncaring. However, a word of warning to the nervous physiotherapist with cold clammy hands; they may not be as reassuring as you may imagine!

Jan Perry (1975) carried out a study on physio therapists whilst they were treating patients to discover the content of their nonverbal communication and 
found that touching the patient was the second most commonly used alter facial expression. By touching the patient the physiotherapist communicates acceptance e.g. touching the stump of an amputated leg demonstrates that the deformity is acceptable to her; touching the patient with severe skin disease or burns demonstrates that the patient is not repulsive and an outcast. We use our hands as professional tools to stabilise, to stimulate and at the same time to reassure and to comfort. In a nontouching society touching as a form of acceptance and support is a privilege given to physiotherapists.

\section{Proximity}

Another unique aspect of the physiotherapist/patient relationship is the proximity or intimacy of the treatment setting. Society, or at least that of the white population, does not accept close physical encounters except between emotionally close persons. In the treatment setting, physical closeness even to the point of touching cannot be avoided.

Jan Perry (1975) stated: "The message potential of closeness during treatment certainly should not be used carelessly; even more emphatically, it should not be ignored or go unrecognised by the physiotherapist. The information available to the patient at this distance is so vivid and could be so beneficial, that the therapist would appear to be doing an injustice to the patient if she is unaware of the significance of the physical closeness during treatment and fails to use this message system effectively."

\section{Facial Expression}

The face is the primary communicator of emotion status. In the study carried out by Jan Perry (1975) facial expressions and more specifically eye contact and smiling made up $40 \%$ of the nonverbal communication between patient and physiotherapist and was seen to establish rapport and encouragement. The physiotherapist may convey by her smile that she is friendly and well disposed towards the patient and her eyes may comnland trust and confidence. Avoiding another's glance and averting your gaze makes for poor interaction and communication.

\section{Written Communication}

Perhaps tlais is an area of communication where phy- siotherapists are at their absolute worst. The professional Communication Unit at the University of Cape Town in collaboration with the School of Social Work have this to say about written communication: "Professional communication demands that your purpose should be clearly defined if you wish to communicate effectively. It is essential to determine what response you want from your reader. Do you want him to understand and accept new information? Do you want him to change his viewpoint to yours and do something as a result? Do you want to convey to hin or her what you have been experiencing?"

One aspect of medical records I would like to mention is that from the legal point of view, medical records must be accurate and objective, as it is possible that your records might be used as evidence in a court case. This is already happening in North America.

\section{CONCLUSION}

Different facets of communication are being used daily by physiotherapists. More time should be spent if studying communication for our patients and ourselves. Finally I would like to finish with this quotation:

One cannot not communicate

Activity or inactivity

words or silence

All have a message value.

(Hooper, 1979)

\section{REFERENCES}

Conine, T. A. (1976). Listening in the helping relationship. Phys. Ther., 56, $159-162$.

Derito, J. A. (1980). The interpersonal communication book. Harper \& Row. New York.

Hislop, H. (1975). The not-so-impossible dream. Phys. Ther, 55, $1069-1080$.

Hooper, R. (1979). The human message systems. Harper \& Row. New York.

Lorber, J. (1975). Good patients \& problem patients: conformity \& deviance in a general hospital. $J$. of Heallh \& Social Bchaviom', 16, 213-225.

Perry, J. F. (1975). Nonverbal communication during physical therapy, Phys. Ther., 55, 593-600.

Purtilo, R. B. (1976): Similarities in patient response to chronic \& terminal illness. Phys. Ther., 56, $279-284$.

Pultilo, R. B. (1978): Health prolessional/patient inter-; action. Sanders, USA. 